\title{
Using Peer Response Groups in ESL Writing Classes
}

James H. Bell

Theories of adult education, composition, and ESL encourage the use of peer response groups in teaching writing. But using such groups is difficult. I describeand provide the rationale for-a rather structured method I developed as a transi- tion between no writing groups and the freer writing groups students might join in the future. The method worked very well with upper intermediate/advanced students in a college setting.

Why should anyone use peer response groups with adult ESL students learning to write? Theories in the fields of adult education, composition, and English as a second language supply compelling reasons. One of the two major positions in contemporary adult education, represented by Knowles (1980), maintains that adults have an inherent need to be selfdirecting and that adult educators should help give expression to this in order to create the lifelong learners which our rapidly changing world demands. The other major position in the field, represented by Brookfield (1986; 1987), agrees that instructors should encourage self-direction but adds that they should foster critical reflection by helping students analyze things and imagine alternatives. Writing groups encourage self-direction because they shift the focus from the teacher to the students. The method which I will describe shortly also encourages critical thinking because students evaluate their own and others essays and suggest alternatives to problematic passages.

Current composition theory also supports the use of peer response groups. Focusing on the writing process more than the written product has created the "process approach" to teaching composition. Intervention during the composing process and an increased consideration of audience are principal tenets of the new approach (Hairston, 1982). Peer response groups intervene between drafts. Audience is emphasized because peers, rather than a teacher, are responding to, rather than grading, a student's writing in the here and now, rather than via marginal comments. Writers get a variety of feedback from a variety of readers, the disparate reactions underscoring the importance of audience.

The composition field is also becoming increasingly aware of writing as a social act. Writing is often more social than solitary. For example, 
when Reither and Vipond (1989) trace the development of an article written at the University of New Brunswick, we see the extent and variety of collaboration: the publication was co-authored, it received extensive peer criticism, and it fit neatly into a field of knowledge being developed by a far-flung intellectual community. Rather than forcing students to compose alone, we should introduce students to the social construction of knowledge (Bruffee, 1984, 1986; Bartholomae and Petrosky, 1986). Peer response groups are an important part of writing as a social activity.

Writing groups are particularly suited to ESL because they employ a variety of language skills: listening (to reading and speaking), reading (aloud and silently), speaking, and writing. Peer response groups are especially suited to certain orientations in the ESL field-for instance, communicative competence. Savignon (1983) lists 6 overlapping tenets of the communicative competence orientation, and all support the use of writing groups. Consider but one tenet: the basic unit of practice should be discourse, not drill patterns. The composition presented to the writing group is an extended attempt to communicate, and, in various ways, group members will tell the writer if they found it meaningful.

Theories of adult education, composition, and ESL encourage the use of peer response groups, but using such groups is difficult, in part because many factors must mesh for success. In my experience, the most common writing group procedure for English as a first language literature is inappropriate for my students. In the method, which comes from Elbow (1973), students form their own groups. A writer, with no apologies or editorializing, reads his or her paper aloud twice to the group. During the first reading, peers record their strongest impressions of the writing, and during the second, they take more detailed notes on what they liked and did not like. Then they tell the writer not so much whether the essay is good or bad but what effects it had on them. Elbow advocated such an approach for adults outside school settings, but it is commonly tried with school children or college students, as Gere and Stevens (1985) and Nystrand (1986) document. Yet, rather unstructured groups may fit poorly within the confines of a classroom and an institution. Elbow himself acknowledges the need for more structure in such situations (personal communication, September, 1990).

I created a more structured approach, a significantly different method, a transition between no writing groups and the free groups advocated by Elbow in Writing Without Teachers. The method worked so well with my upper-intermediate and advanced ESL writers (there was an equal mix of immigrants and visa students in the college classes) that I am passing it on to you. I supply a brief rationale for each step in the method so that you may see some of the factors considered and adapt the procedure to your situation. 


\section{How to Set up Writing Groups in the Classroom}

Explain why the class will use peer response groups as an integral part of the course. Students who are products of strongly teacher-centred schooling may need to be convinced to try something so different. Furthermore, as adults, the students deserve to know why they are doing things. Describe clearly how the groups should work, and supply or have the students make brief outlines of the steps the group will follow. I outline the 6 steps thus:

1. Question (author)

2. Read (author aloud and peers silently)

3. Silence (author and peers)

4. Answer question (peers)

5. Respond-positive and negative (peers)

6. Work on something (author with peers)

Students need a simple model of what the group will do, and it must be handy in head or hand so that the group can stay on track when the discussion gets hectic. If possible, show a peer response group in action, live or on videotape. Seeing a successful group lessens student anxiety, engenders a feeling for the pace of group activity, and makes the steps followed in the writing groups come to life.

Two to three weeks after classes start, or as soon as you have enough knowledge of your students and their writing, create groups for the semester-with the possibility of changes after a midterm reassessment. If class periods are 50 minutes in length and attendance is good, form teams of three. Larger groups can seldom finish responding to all the essays in the allotted time. Take the time to form groups which will work and grow rather than self-destruct.

To illustrate the care with which groups are formed and to reveal some of the factors to consider, I describe the 1-2 hour planning process I use. First I divide the class into high, medium, and low ability levels. This avoids the problem of good writers giving but not receiving substantial assistance. Within each level I try to create groups where no two people speak the same first language. This makes English the language of discussion. I also aim for males and females in each group. One of the salient cultural differences for many of my students is the relatively equal status of men and women in Canada, and writing groups are good places in which to work on this issue. Next, I place a shy, retiring student from the good or average writers with every two poor writers to form groups. The poorer writers grow more in confidence and interpersonal skills. While forming groups, I constantly consider nationalities, personalities, and friendships. This process is more complicated than saying to the class, 
"Okay, form groups of three," but creating teams carefully minimizes the chances of destructive group dynamics.

Each time a group meets, it chooses a timer, whose job is to ensure that each essay receives equal consideration. The group may not move on to another paper until it has spent the allotted time on the paper under discussion. The first semester that I tried writing groups, I did not require timing, and the most common complaint on an end-of-course questionnaire was that some papers were slighted.

When the groups start to deal with papers, they proceed as follows for each student.

1. The writer asks for assistance with one element-or at the most, two elements-in his or her essay. Writers take responsibility for seeking help. Equipped with evaluation skills taught in class, students must evaluate their own writing and decide what aspect requires the most work. This is an important skill for students growing less dependent on instructor judgement. Furthermore, asking for help with something specific gives writers some control over what is said in the groups.

2. With no apologies, with no explanations, the writer reads. Reading aloud not only provides speaking and listening practice, but students can spot errors aurally and develop a sense of how writing can sound. The no-justifications admonition is intended to reinforce the notions that rough drafts are supposed to be rough and that the group will help members as required.

Other group members listen and read a single copy. Because of limited L2 writing, pronunciation, and listening skills, group members usually need a copy in order to understand what a writer is trying to say. They also need the copy to work with once the writer has finished reading. Nystrand (1986) found that even with English as a first language, students, having a copy of the paper correlated with substantial as opposed to superficial comments.

3. When the writer has finished reading, there is at least 60 seconds silence. Group members need time to think, to look back through the paper, to marshal support for their answer to the writer's question.

4. The group members answer the writer's question, in turn. They should support their answers. Answering the writers' questions reinforces that the writers are in charge and that the group is to help. Authors have not been tossed to a pack of vicious critics. When writers have their concerns addressed, they feel that the peer response group is useful, that it actually helps them revise. That is also why it is important that group members support answers. "I liked your introduction" tells an author little. In contrast, the following response reveals in valuable detail how the prose is working on people: "I liked your introduction (why?) because it caught my interest (why?) because, like many immigrants, I often think of visiting 
my home country. So as soon as you mentioned your trip home, I wondered if it met your expectations."

5. Group members respond more freely to the composition, pointing to something they like and to something they think needs improving. They explain their responses. This freer response is crucial: writers have tried to communicate, and group members let them know where they have succeeded and failed. Because students, like instructors, tend to dwell on the failures, a positive comment is required to balance every criticism. For the first essay of the semester, I allow only positive comments in this step. Not only is praise a good teacher, but students often need encouragement in the face of rewriting. "Pointing," a technique borrowed from Elbow (1973, p. 85-86), engenders specificity. Students should actually point to passages and say, for example, "The thing I like best in your essay was the example you used in the second paragraph, here, where you say. . .."

6. The writer chooses something to work on, and the group helps. Group members must do more than critique; they must also create. This builds team spirit and supplies further evidence that the writing group is worthwhile. Moreover, writers often realize that something needs revising but do not know how to proceed. Writers can try out revisions on the group, and the group can suggest revisions and revision methods to the writers.

When the group is commenting on a draft, writers take notes, preferably quick marginal notes. If you want to test the necessity of this procedure, at the end of class ask students who presented papers early in the period what comments were made on their essays. I have found that they usually remember about half. Beaumont (1978) found a positive correlation between taking notes during response group discussions and making successful revisions.

When the group offers feedback, writers do not argue or offer justifications and rationalizations. Instead, if comments perplex them, they ask for clarification and additional information. After all, the writer's principal purpose is to receive feedback. The writer can select and reject the advice later.

Meanwhile, the instructor monitors. Is the group following the procedure? If not, tell the members. (I do not always insist that students adhere strictly to steps 5 and 6 ; if the power of peer response is working, I let the students direct the discussion as they see fit.) Are the students making substantive comments? Note that this does not ask whether they are making the same comments that an instructor might make. Is a group having trouble sorting trivial suggestions from substantive ones? If so, pick the most perspicacious comment and say that you agree with it. That's all. In order to monitor in this way, you usually need to sit in a group for the presentation and discussion of one paper. Thus more than three or four 
groups per period is awkward. I have half the class attend one period, and half the next.

Finally, praise the groups or the class for good group work.

\section{Closing Remarks}

I designed the above method as a transition from the teacher-centred classrooms most students know to the more free-form writing groups students may join in the future. I have been happy with the results. So have most students. On an anonymous, open-ended questionnaire distributed at the end of one semester, students said that the 2 things they like best about writing class were learning to write different types of essays and working in writing groups. All recommended using peer response groups again. To increase the chances of writing groups working for you, establish a classroom context hospitable to group work. I believe such a climate is built by many small things such as the following: when students ask questions, have other students answer on occasion; when you ask a question and a student responds, do not always restate the answer; and when a student adds a significant concept to the lesson, incorporate it more than once, mentioning the student's name. Such techniques help to establish students as knowledgeable writers worth listening to. If, in contrast, the classroom context continually establishes the instructor as the only expert on composition, students entering a peer response group will expect to hear nothing worthwhile.

Writing groups work best when they are integrated into the course. Mention them the first day of classes, start them fairly early, and use them regularly. Two semesters ago, my groups met every Friday for 50 minutes; last semester they met every second Friday for 75 minutes. Trying writing groups once or twice a semester for methodological variety courts failure.

If you try peer response groups as I have described-or try some variation to suit your situation-I would be interested to hear how things went.

\section{ACKNOWLEDGEMENTS}

The author would like to thank Fran Galbraith, Phyllis Pankratz, and David Wood for comments on an earlier draft of this paper.

\section{REFERENCES}

Bartholomae, D. \& Petrosky, A.R. (1986). Facts, artifacts, and counterfacts: Theory and method for a reading and writing course. Upper Montclair, NJ: Boynton/Cook.

Beaumont, P.A. (1978). A descriptive study of the tutor in a conference on writing. Unpublished master's thesis, University of San Diego. 
Brookfield, S.D. (1987). Developing critical thinkers: Challenging adults to explore alternative ways of thinking and acting. San Francisco: Jossey-Bass.

Brookfield, S.D. (1987). Developing critical thinkers: Challenging adults to explore alternative ways of thinking and acting. San Francisco: Josey-Bass.

Bruffee, K.A. (1984). Collaborative learning and the "conversation of mankind." College English, 46, 635-652.

Bruffee, K.A. (1986). Social construction, language, and the authority of knowledge: A bibliographic essay. College English, 48, 773-790.

Elbow, P. (1973). Writing without teachers, London: Oxford University Press.

Gere, A.R. \& Stevens, R.S. (1985). The language of writing groups: How oral response shapes revision. In S. W. Freedman (Ed.), The acquisition of written language: Response and revision (pp. 85-105). Norwood, NJ: Ablex.

Hairston, M. (1982). The winds of change: Thomas Kuhn and the revolution in the teaching of writing. College Composition and Communication, 33(1), 7688 .

Knowles, M.S. (1980). The modern practice of adult education: From pedagogy to andragogy. New York: Cambridge.

Nystrand, M. (1986). Learning to write by talking about writing: A summary of research on intensive peer review in expository writing instruction at the University of Wisconsin-Madison. In M. Nystrand (Ed.), The structure of written communication (pp. 179-211). Orlando, FL: Academic Press.

Reither, J.A. \& Vipond, D. (1989). Writing as collaboration. College English, $51(8), 855-867$.

Savignon, S.J. (1983). Communicative competence: Theory and classroom practice. Reading, MA: Addison-Wesley.

\section{THE AUTHOR}

Last year Jim Bell (PhD University of Texas) taught writing and reading courses in The Languages Institute at Mount Royal College, Calgary. This year he is promoting and coordinating adult literacy activities in Calgary. He is particularly interested in one-to-one teacher-student conferences, peer tutoring, and writing groups. He may be contacted at 2204-1 St. S. W. \#201, Calgary, AB T2S 1P4. 